\title{
EFEKTIVITAS STRATEGI PEMBELAJARAN KEKUATAN BERDUA TERHADAP KEMAMPUAN MENGIDENTIFIKASI UNSUR INTRINSIK PUISI OLEH SISWA KELAS X SMA NEGERI 1 PAHAE JULU TAHUN PEMBELAJARAN 2016/2017
}

\author{
Oleh \\ Chanrika Natalina $S$ \\ Dra. Rosdiana Siregar, M.Pd.
}

\begin{abstract}
ABSTRAK
Penelitian ini bertujuan untuk mengetahui keefektivan Strategi Kekuatan Berdua dalam pembelajaran mengidentifikasi unsur intrinsik puisi. Populasi dalam penelitian ini berjumlah 103 siswa kelas X SMA Negeri 1 Pahae Julu. Sampel dalam penelitian ini berjumlah 26 orang yang diambil dengan teknik random sampling. Instrumen yang digunakan untuk menjaring data adalah tes esai. Metode yang digunakan dalam penelitian ini adalah metode eksperimen. Pengujian hipotesis dilakukan dengan menggunakan uji " $t$ ". Dari pengolahan data, diperoleh nilai rata-rata pre test $=50$, standar deviasi $=7,62$, dan termasuk dalam kategori baik dan baik tidak ada atau $0 \%$, kategori cukup sebesar $42 \%$ sebanyak 11 orang siswa, kategori kurang sebesar 57\% sebanyak 15 orang siswa dan kategori sangat kurang sebanyak $0 \%$. Nilai rata-rata post test $=61.5$, standar deviasi $=8.56$, dan termasuk dalam kategori, yaitu kategori sangat baik tidak ada, kategori baik sebanyak 15,3\% sebanyak 4 siswa, kategori cukup 69,2\% sebanyak 18 siswa, dan kategori kurang sebanyak 15,3\% sebanyak 4 siswa, sedangkan kategori sangat kurang tidak ada atau $0 \%$. Berdasarkan uji normalitas, hasil pre test dan post test berdistribusi normal. Kemudian berdasarkan uji homogenitas dinyatakan bahwa sampel berasal dari populasi yang homogen. Setelah uji homogenitas dan normalitas dilakukan, maka diketahui $\mathrm{t}_{0}$ sebesar 5,04 selanjutnya $\mathrm{t}_{0}$ tersebut dikonsultasikan dengan tabel $\mathrm{t}$ dengan taraf signifikan $\alpha 5 \%$ dengan satu pihak dimana $\mathrm{dk}=(\mathrm{n}-$ 1) maka $t_{\text {tabel }}=2,05$ sehingga jika dibandingkan dengan $t_{0}$ dengan $t_{\text {tabel }}$ maka $t_{0}>t_{\text {tabel }}(5,04>$ 2,05) maka hipotesis nihil $\left(\mathrm{H}_{0}\right)$ ditolak dan hipotesis alternatif $(\mathrm{Ha})$ diterima. Akhirnya dapat disimpulkan bahwa penggunaan Strategi Pembelajaran Kekuatan Berdua berpengaruh positif terhadap kemampuan mengidentifikasi unsur intrinsik puisi kelas X SMA Negeri 1 Pahae Julu Tahun Pembelajaran 2016/2017.
\end{abstract}

Kata Kunci : Strategi kekuatan berdua, unsur intrinsik puisi, mengidentifikasi unsur intrinsik.

\section{PENDAHULUAN}

Strategi belajar adalah salah satu cara yang dapat digunakan oleh siswa untuk dapat belajar mengolah pikiran sendiri. Pembelajaran harusnya berpusat pada siswa, sehingga diharapkan siswa bertindak aktif dan guru bertindak sebagai fasilitator. Namun, seringkali yang terjadi adalah siswa hanya berlaku sebagai objek tanpa keterlibatan aktif di dalam pembelajaran. Guru diharapkan mengembangkan atau mencari alternatif yang digunakan untuk membingbing strategi belajar. Pada dasarnya tidak ada strategi yang paling ideal. Masing-masing strategi mempunyai kelebihan dan kekurangan masing-masing. Hal ini sangat 
bergantung pada tujuan yang hendak dicapai, pengguna strategi (guru), ketersediaan fasilitas , dan kondisi siswa.

Keterkaitan pemilihan strategi dalam mengajar dimaksudkan sebagai daya upaya guru dalam menciptakan suatu sistem lingkungan yang memungkinkan terjadinya proses mengajar. Maksudnya agar tujuan pengajaran yang telah dirumuskan dapat tercapai. Hal itu senada dengan pendapat Sanjaya (2012) yang mengungkapkan bahwa strategi digunakan untuk memperoleh kesuksesan atas keberhasilan dalam mencapai tujuan. Jadi, strategi pembelajaran dapat diartikan sebagai perencanaan yang berisi tentang rangkaian kegiatan yang didesain untuk mencapai tujuan pendidikan tertentu.

Strategi pembelajaran adalah suatu kegiatan pembelajaran yang harus dikerjakan guru dan siswa agar tujuan pembelajaran dapat tercapai secara efektif dan efisien. Untuk mencapai tujuan pembelajaran perlu disusun suatu strategi agar tujuan itu tercapai dengan optimal. Kemp (dalam Ngalimun, 2014) menjelaskan bahwa strategi pembelajaran adalah suatu kegiatan pembelajaran yang harus dikerjakan guru dan siswa agar tujuan pembelajaran dapat dicapai secara efektif dan efisien. Kozma (dalam Sanjaya, 2012) secara umum menjelaskan bahwa strategi pembelajaran dapat diartikan sebagai kegiatan yang dipilih, yaitu dapat memberikan fasilitas atau bantuan kepada peserta didik menuju tercapainya tujuan pembelajaran tertentu.

Pembelajaran apresiasi sastra indonesia bertujuan mengembangkan kepekaan siswa terhadap nilai-nilai indrawi, nilai akali, nilai afektif, nilai keagamaan, dan nilai sosial, secara sendiri-sendiri atau gabungan keseluruhan seperti yang tercermin di dalam. Umumnya bahasa yang dipakai dalam karya sastra mempunyai makna yang luas dan selalu memerlukan pemahaman yang luas pula. Kadang-kadang maksud pengarang itu dituangkan dalam karangan puisi yang sulit dipahami. Oleh karena itu bahasa sastra harus memerlukan pemahaman dan pengertian yang dalam. Pembelajaran sastra di SMA bertujuan agar peserta didik dapat mengapresiasikan karya sastra di Indonesia dan dapat menkomunikasikannya, baik secara lisan maupun tulisan.

Untuk mencapai tujuan itu, butir pembelajaran yang berupa menyunting karangan sendiri atau orang lain amatlah esensial dan vital. Hal ini disebabkan akan menunjang kemampuan dalam menganalisis karya sastra khususnya puisi. Kenyataan yang dihadapi oleh sebagian siswa, kemampuan esensial itu kurang dimiliki siswa secara optimal.

Munculnya kesulitan seseorang dalam memahami puisi, antara lain disebabkan karena adanya idiom yang digunakan dalam puisi antara yang sudah dikenal dan yang belum dikenal sebelumnya, perbedaan realita sosial pembaca, pembaharuan yang terus terjadi pada puisi 
tidak secara langsung diterima oleh pembaca umumnya, dan penikmat puisi tidak berusaha memahami dengan sungguh-sungguh.

Bukti mengenai pembelajaran yang dilakukan guru dalam menganalisis unsur intrinsik puisi terdapat dalam jurnal Pendidikan dan Pengajaran tahun 2006 ,Made Sri Indriani yang berjudul "Meningkatkan Kemampuan Menganalisis Puisi Dengan Pengajaran Pemahaman Unsur Intrinsik Karya Sastra Untuk Meningkatkan Kemampuan Menganalisis Puisi Siswa Kelas III A1 Sma Negeri 2 Singaraja", pembelajaran yang selama ini dilakukan, yaitu (1) mengadakan tanya jawab antara guru dan siswa tentang topik yang dijadikan topik pembicaraan, agar terjadi persamaan persepsi, (2) menunjuk secara acak siswa untuk membacakan hasil karyanya (3) siswa lainnya membandingkan hasil karyanya sendiri, (4) setelah siswa selesai membacakan pekerjaannya, guru merevisinya agar tersusun lebih baik dan siswa memperhatikan untuk bias diketahui kekurangan dan kekeliruannya dalam memberikan penilaian tentang karya sastra yang dianalisisnya.

Namun setelah diadakan pengamatan secara cermat bahwa faktor penyebabnya adalah siswa belum menguasai teknik dalam menganalisis puisi walaupun telah dilibatkan secara langsung. Dalam menganalisis karya sastra, kemungkinan hal ini terjadi karena beberapa faktor diantaranya: kurangnya kemampuan pemahaman tentang unsur intrinsik karya sastra khususnya, kemudian dalam mengungkapkannya siswa dituntut untuk mengungkapkan dengan bahasa Indonesia yang baik dan benar.

Kesulitan siswa yang berdampak pada rendahnya kompetensi mengapresiasi puisi disebabkan olen beberapa faktor. Salah satunya adalah guru. Faktor yang dimaksud adalah cara guru menyampaikan pelajaran kurang menarik, guru jarang menggunakan media, dan penilaian yang dilakukan guru berupa teori. Faktor lain adalah kurangnya minat siswa dalam belajar dan cara belajar mereka pun masih sangat monoton, siswa hanya disuruh membaca tanpa membuat mereka lebih aktif dengan cara memberi pertanyaan ataupun membuat permainan agar pelajaran terkesan menarik.

Sesuai dengan penelitian yang dilakukan oleh Aziz Amin Muhajidin (2012) dalam jurnalnya yang berjudul "Keefektifan Pembelajaran Apresiasi Puisi dengan Analisis Struktural dan Analisis Semiotik Berdasarkan Gaya Berpikir Sekuensial-Acak Pada Siswa $S M P$ ", hal ini dapat terlihat secara nyata ketika mengamati serta menilai pembelajaran apresiasi sastra selama ini berlangsung monoton, tidak menarik bahkan membosankan. Siswa jarang sekali diajak untuk menjelajahi dan menggauli keagungan nilai yang terkandung dalam teks sastra, tetapi sekedar dicekoki dengan pengetahun-pengetahuan tentang sastra 
yang bercorak teoretis dan hafalan. Mereka jarang diminta mengapresiasi teks sastra yang sesungguhnya, tetapi sekedar menghafalkan nama-nama sastrawan berikut hasil karyanya. Dengan kata lain, apa yang disampaikan pengajar dalam pengajaran hanyalah kulitnya saja, sehingga peserta didik tidak akan pernah bisa menemukan keindahan dan nilai-nilai yang terkandung dalam karya sastra.

Berkaitan dengan hal ini kenyataan yang muncul nilai siswa dalam mengidentifikasi unsur instrinsik puisi masih rendah. Fenomena ini didukung oleh penelitian sebelumnya. Dari hasil penelitian Mayati Pasaribu dalam skripsinya yang berjudul "Pengaruh Penerapan Model ATI (Attitude Treatment Intraction) Terhadap Kemampuan Siswa Mengidentifikasi Unsur Intrinsik Puisi Generasi Biru Karya Toha Nasrudin Oleh Siswa Kelas X”, nilai siswa dalam mengidentifikasi unsur instrinsik puisi pada nilai rata-rata 53,57. Dalam hal ini nilai tersebut perlu ditingkatkan. Untuk memperbaiki proses dan hasil pembelajaran yang efektif, maka peneliti menyuguhkan sebuah teknik yang menarik yaitu The Power Of Two. The Power Of Two dirancang untuk menghindari pembelajaran berpusat pada guru. Suatu jangkauan alternatif yang luas disediakan, kesemuanya adalah yang mendorong para peserta didik memperoleh pengetahuan, keterampilan secara aktif.

Strategi The Power Of Two termasuk bagian dari active learning yang merupakan salah satu cara terbaik untuk meningkatkan belajar lebih aktif dengan pemberian tugas belajar lebih aktif. Dukungan sesama siswa dan keragaman pendapat, pengetahuan serta keterampilan mereka akan membantu menjadikan belajar menjadi bagian yang berharga. Dengan metode belajar yang berpusat pada siswa diharapkan strategi ini akan efektif digunakan dalam mengidentifikasi unsur intrinsik puisi

Keberhasilan penggunaan strategi The Power Of Two didukung oleh penelitian Budi Arti Rahayu dengan judul "Penerapan Strategi Pembelajaran The Power Of Two Dalam Upaya Meningkatkan Hasil Belajar Aqidah Siswa Kelas VII.1 MTS Syaroful Millah Penggaron Kidul Semarang”. Hasil penelitian menunjukkan bahwa keaktifan peserta didik meningkat yakni dari presentasi 58,15 menjadi 70,75. Dan melalui penggunaan strategi ini juga hasil belajar siswa meningkat yang semula memiliki presentasi 40,91 menjadi 54,54. Selanjutnya Yuanita Resti, dengan judul penelitian "Penerapan Strategi Pembelajaran Aktif Tipe The Power Of Two (Kekuatan Berdua) Dengan Media Gambar Untuk Meningkatkan Kreativitas Dan Prestasi Belajar Bahasa Indonesia”. Dalam hal prestasi belajar siswa di setiap siklusnya mengalami peningkatan, hal tersebut dapat ditunjukkan dari rata-rata skor nilai siswa, terlihat adanya peningkatan prestasi siswa dari pra penelitian ke siklus I dan ke siklus II, pra penelitian sebesar 70,60 pada siklus I sebesar 81,71 pada siklus II menjadi 86,62 
atau meningkat sebesar 16,02 yang berarti sudah memenuhi KKM (Kriteria Ketuntasan Minimum) madrasah tersebut yaitu sebesar 75 .

\section{METODE PENELITIAN}

Metode merupakan bagian yang penting dalam suatu pelaksanaan penelitian. Hal ini disebabkan karena berhasil atau tidaknya kegiatan yang akan dilakukan dalam penelitian sangat bergantung pada metode yang digunakan. Sesuai dengan pendapat Sugiyono (2013:6) menyatakan "metode penelitian adalah cara yang ilmiah yang mendapatkan data yang valid dengan tujuan dapat ditemukan, dikembangkan, dan dibuktikan, suatu pengetahuan tertentu dapat digunakan untuk memahami dan memecahkan masalah dalam bidang pendidikan”.

Metode yang digunakan dalam penelitian ini adalah metode eksperimen. Hal ini sejalan dengan pendapat Arikunto (2013:207) yang mengatakan bahwa " Penelitian eksperimen merupakan penelitian yang dimaksudkan untuk mengetahui ada tidaknya akibat dari 'sesuatu' yang dikenakan pada subjek selidik". Dengan kata lain, penelitian eksperimen mencoba meneliti ada tidaknya pengaruh dari suatu perlakuan dengan One group pre-test post-test design, yaitu tanpa menggunakan kelompok pembanding. Metode ini digunakan untuk mengetahui efektivitas strategi The Power Of Two terhadap kemampuan mengidentifikasi puisi siswa kelas X SMA Negeri 1 Pahae Julu tahun pelajaran 2016/2017.

Data yang diperoleh selanjutnya dianalisis secara statistik dengan langkah-langkah analisis yaitu data hasil post test disusun dalam bentuk tabel, menentukan nilai rata-rata dan standar deviasi dari kedua data sampel, menghitung uji normalitas, uji homogenitas, dan uji hipotesis. Setelah t diketahui maka nilai tersebut akan dikonsultasikan dengan tabel pada taraf signifikan 5\% dengan derajat kebebasan $(\mathrm{dk})=\mathrm{n}-1$ pada taraf nyata $\alpha=0.05$. Dengan demikian jika $t_{0}>t_{t}$ pada taraf nyata $\alpha=0.05$ maka Ha diterima.

\section{HASIL PENELITIAN DAN PEMBAHASAN}

\section{Hasil Penelitian}

\section{a. Kemampuan Mengidentifikasi Unsur Intrinsik Puisi Sebelum Menggunakan Strategi Kekuatan Berdua}

Berdasarkan data pre-test dapat diketahui bahwa rata-rata kemampuan siswa mengidentifikasi unsur intrinsik puisi sebelum menggunakan strategi kekuatan berdua adalah 50, standar deviasi yang diperoleh 7.62, dan standar eror 1.52. Secara umum gambaran nilai 50 merupakan kategori kurang.

Pada tema, yang mendapatkan skor 5 sebanyak 8 siswa, skor 3 sebanyak 17 siswa dan skor 0 sebanyak 1 siswa. Rata-rata skor pada tema adalah 3.52. Nada, yang mendapatkan 
skor 5 sebanyak 2 siswa dan skor 3 sebanyak 23 siswa. Rata-rata skor pada nada adalah 3.05. Perasaan, yang mendapatkan skor 5 sebanyak 1 siswa dan skor 3 sebanyak 23 siswa dan skor 0 sebanyak 2 siswa. Rata-rata skor pada perasaan adalah 2.84. Amanat, yang mendapatkan skor 5 sebanyak 1 siswa, skor 3 sebanyak 2 siswa dan skor 0 sebanyak 2 siswa . Rata-rata skor pada amanat adalah 2.84. Pemilihan kata, yang mendapatkan skor 5 sebanyak 0 siswa, skor 3 sebanyak 25 siswa, dan skor 0 sebanyak 1 siswa. Rata-rata skor pada pemilihan kata adalah 2.88. Kata konkret, yang mendapatkan skor 5 sebanyak 0 siswa, dan skor 3 sebanyak 15 siswa dan skor 0 sebanyak 11 siswa. Rata-rata skor pada kata konkret adalah 2. Pengimajian, yang mendapatkan skor 5 sebanyak 1 siswa, skor 3 sebanyak 23 siswa, skor 0 sebanyak 2 siswa. Rata-rata skor pada pengimajian adalah 2.84

Dari data di atas dapat disimpulkan bahwa rata-rata nilai perkriteria adalah kurang, dengan nilai terendah yang diperoleh siswa sebelum menggunakan adalah 42, nilai tertinggi adalah 68 , dan nilai rata-rata adalah 50 . Ternyata dari temuan tersebut bukan merupakan hasil yang diharapkan. Hal ini disebabkan siswa masih berlatih dengan menggunakan model pembelajaran yang mereka rasa membosankan sehingga tidak menumbuhkan minat belajar siswa. Itulah faktanya di lapangan. Pada tahap sebelum menerapkan strategi kekuatan berdua siswa berlatih untuk meningkatkan kemampuan mengidentifikasi hanya dengan apa yang mereka tahu saja tanpa di arahkan bagaimana cara menulis berita dengan baik.

\section{b. Kemampuan Mengidentifikasi Unsur Intrinsik Puisi Menggunakan Strategi Kekuatan Berdua.}

Berdasarkan data post-test dapat diketahui bahwa rata-rata kemampuan siswa mengidentifikasi unsur intrinsik puisi setelah menggunakan strategi Kekuatan Berdua adalah 61,5 , standar deviasi yang diperoleh 8.56 dan standar eror 1.71. Secara umum gambaran nilai 61.5 merupakan kategori cukup.

Dalam mengidentifikasi tema puisi, siswa yang mendapatkan skor 5 sebanyak 11 siswa, skor 3 sebanyak 15 siswa dengan rata-rata sebesar 3.84. Pada nada, siswa yang mendapatkan skor 5 hanya 3 siswa, skor 3 sebanyak 23 siswa dengan rata-rata sebesar 3.23. Sedangkan pada perasaan, siswa yang mendapat skor 5 sebanyak 2 siswa, skor 3 sebanyak 23 siswa, skor 0 hanya 1 siswa dengan rata-rata sebesar 3.02. Pada amanat, siswa yang mendapat skor 5 sebanyak 2 siswa, skor 2 sebanyak 22 siswa dan skor 0 sebanyak 2 siswa dengan nilai rata-rata sebesar 2.92. Selanjutnya pada pemilihan kata, siswa yang mendapat skor 5 sebanyak 5 siswa dan mendapat skor 3 sebanyak 21 siswa dengan nilai rata-rata sebesar 3.38. Lalu pada kata konkret, siswa yang mendapat skor 5 tidak ada dan mendapat 
skor 3 sebanyak 21 siswa dengan nilai rata-rata sebesar 2.53. Pada pengimajian, siswa yang mendapat skor 5 sebanyak 2 siswa, skor 3 sebanyak 21 dengan nilai rata-rata sebesar 3.36.

Dari data di atas dapat disimpulkan bahwa rata-rata nilai perkriteria adalah baik, dengan nilai terendah yang diperoleh siswa setelah menggunakan strategi Kekuatan Berdua adalah 45, nilai tertinggi adalah 77, dan nilai rata-rata adalah 61.5. Melalui data diperoleh dapat juga diketahui bahwa telah terjadi peningkatan, artinya Strategi Kekuatan Berdua dalam proses pembelajaran sangat berpengaruh terhadap peningkatan kemampuan mengidentifikasi unsur intrinsik puisi. Strategi kekuatan berdua dalam mengidentifikasi unsur intrinsik puisi menuntut siswa menjadi aktif dalam mencari dan mengidentifikasi teks puisi baik melakukan dengan sendiri ataupun melakukannya dengan kelompok, sehingga siswa semakin termotivasi dan tertarik, dan lebih mudah untuk mengidentifikasi unsur intrinsik puisi.

\section{Pembahasan Hasil Penelitian}

Berdasarkan hasil penelitian dapat diperoleh gambaran atau simpulan bahwa kemampuan mengidentifikasi unsur intrinsik puisi oleh siswa siswa SMA Negeri 1 Pahae Julu Tahun Pembelajaran 2016/2017 dengan hasil rata-rata 61.5 dan dapat dikategorikan cukup.

Ada tujuh aspek yang dinilai dalam kemampuan mengidentifikasi unsur intrinsik puisi, yaitu kemampuan mengidentifikasi tema, kemampuan mengidentifikasi nada, kemampuan mengidentifikasi perasaan, kemampuan mengidentifikasi amanat, kemampuan mengidentifikasi pemilihan kata, kemampuan mengidentifikasi kata konkret dan kemampuan mengidentifikasi pengimajian. Adapun perolehan skor siswa pada masing-masing aspek adalah sebagai berikut.

\section{a. Kemampuan Mengidentifikasi Tema}

Kemampuan mengientifikasi tema merupakan salah satu aspek penilaian dalam mengidentifikasi unsur intrinsik puisi. Penilaian aspek ini dinyatakan dalam bentuk skor dan skor maksimal yang diperoleh adalah 5. Dalam mengidentifikasi tema puisi, siswa yang mendapatkan skor 5 sebanyak 11 siswa, skor 3 sebanyak 15 siswa dengan rata-rata sebesar 3.84 dan dengan perolehan tersebut nilai siswa mengalamai peningkatan dari hasil sebelumnya yaitu 3,52 dengan selisih 0.32. Berdasarkan nilai rata-rata tersebut kategori skor yang diperoleh siswa dalam mengidentifikasi tema termasuk dalam kategori cukup.

Untuk mengetahui rata-rata nilai yang diperoleh siswa dalam mengidentifikasi unsur intrinsik tema, nilai rata-rata tersebut diklasifikasikan berdasarkan nilai kemampuan menurut 
Sudjiono (2009:740). Oleh karena itu, nilai rata-rata dibagian skor maksimal (5) lalu dikalikan seratus (100) Jadi nilai rata-rata yang diperoleh adalah 70.4. Dengan demikian dapat disimpulkan bahwa kemampuan siswa dalam mengidentifikasi tema tergolong dalam kategori cukup.

Pada aspek mengidentifikasi unsur intrinsik tema siswa tidak mengalami kesulitan karena siswa mampu memahami apa yang dimaksud dengan tema, dan siswa telah mengerti bagaimana cara menganalisisnya siswa tidak perlu melakukan penelaahan lebih lagi.

\section{b. Kemampuan Mengidentifikasi Nada}

Kemampuan mengidentifikasi nada adalah aspek penilaian selanjutnya dalam mengidentifikasi unsur intrinsik puisi. Dengan skor maksimal yang harus diperoleh adalah 5 dan skor minimal adalah 3. Pada aspek nada, siswa yang mendapatkan skor 5 hanya 3 siswa, skor 3 sebanyak 23 siswa dengan rata-rata sebesar 3.23.

Perolehan rata-rata tersebut mengalami peningkatan dari rata-rata nilai pre test 3.05 dengan selisih 0.18. Berdasarkan nilai rata-rata tersebut kategori skor yang diperoleh siswa sudah memenuhi harapan karena skor maksimal yang harus diperoleh adalah 5. Untuk mengetahui rata-rata nilai yang diperoleh siswa dalam mengidentifikasi unsur intrinsik nada, nilai rata-rata tersebut diklasifikasikan berdasarkan nilai kemampuan menurut Sudjiono (2009:740). Oleh karena itu, nilai rata-rata (3.08) dibagian skor maksimal (5) lalu dikalikan seratus (100). Jadi nilai rata-rata yang diperoleh adalah 66.4. Dengan demikian dapat disimpulkan bahwa kemampuan siswa dalam mengidentifikasi nada tergolong dalam kategori cukup.

\section{c. Kemampuan Mengidentifikasi Perasaan}

Kemampuan mengidentifikasi perasaan pada puisi adalah salah satu aspek dalam mengidentifikasi unsur intrinsik puisi. Penilain aspek ini dinyatakan dalam bentuk skor dan skor maksimal yang harus diperoleh adalah 5. Pada aspek ini siswa yang memperoleh skor 5 sebanyak 2 orang siswa dan skor 23 orang siswa, dan rata-rata skor yang diperoleh adalah 3.02. Perolehan nilai rata-rata tersebut mengalami peningkatan dari hasil sebelumnya dengan selisih 0.18 .

Untuk mengetahui rata-rata nilai yang diperoleh siswa dalam mengidentifikasi unsur intrinsik perasaan, nilai rata-rata tersebut diklasifikasikan berdasarkan nilai kemampuan menurut Sudjiono (2009:740). Jadi nilai rata-rata yang diperoleh adalah 60.4. Dengan demikian dapat disimpulkan bahwa kemampuan siswa dalam mengidentifikasi nada tergolong dalam kategori kurang. 
Kesulitan siswa dalam mengidentifikasi unsur ini adalah siswa kurang mampu dalam memahami perasaan dari si penulis karena siswa tidak mampu menelaah dan mengekspresikan keadaan penulis pada saat puisi tersebut dibacakan.

\section{d. Kemampuan Menganalisis Amanat}

Kemampuan menganalisis amanat juga termasuk dalam aspek penilaian mengidentifikasi unsur intrinsik puisi dalam hal ini siswa diajak untuk mengidentifikasi atau menemukan pesan-pesan tersirat dari puisi. Pada aspek ini siswa yang mendapat skor 5 sebanyak 2 siswa dan yang mendapat skor 3 sebanyak 22 siswa dengan nilai rata-rata 2.92. Jadi skor sata-rata yang diperoleh dalam aspek ini adalah 58.4 dan hasil ini jauh dari yang diharapkan karena dalam kategori kurang.

Kesulitan siswa yang ditemukan pada saat mengidentifikasi unsur ini adalah siswa tidak paham akan berbagai temuan kosa kata baru yang menyulitkan mereka menyimpulkan maksud dan tujuan si penulis, selain itu siswa juga tidak memiliki pemahaman penuh tentang puisi.

\section{e. Kemampuan Mengidentifikasi Pemilihan Kata}

Mengidentifikasi pemilihan kata merupakan salah satu aspek penilaian dalam mengidentifikasi puisi. Penilaian dalam aspek ini dinyatakan dalam bentuk skor, dan skor maksimal yang harus diperoleh adalah 5. Dalam hal ini siswa yang mendapatkan nilai 5 sebanyak 5 siswa dan skor 3 sebanyak 21 siswa dengan nilai rata-rata yang diperoleh 3.38.

Untuk mengetahui rata-rata nilai yang diperoleh siswa dalam mengidentifikasi unsur intrinsik pemilihan kata, nilai rata-rata tersebut diklasifikasikan berdasarkan nilai kemampuan menurut Sudjiono (2009:740). Jadi nilai rata-rata yang diperoleh adalah 67.6. Dengan demikian dapat disimpulkan bahwa kemampuan siswa dalam mengidentifikasi pemilihan kata tergolong dalam kategori cukup.

\section{f. Kemampuan Mengidentifikasi Kata Konkret}

Salah satu aspek penilaian dalam megidentifikasi unsur intrinsik puisi kemampuan mengidentifikasi kata konkret. Pada aspek ini skor maksimal yang harus diperoleh adalah 5. Siswa yang mendapat nilai 5 tidak ada dan yang memperoleh skor 3 sebanyak 21 siswa dan yang tidak berhasil menjawab sebanyak 5 siswa dengan perolehan rata-rata nilai adalah 2.52. Perolehan tersebut mendapatkan peningkatan dari perolehan sebelumnya dengan selisih 0.46.

Untuk mengetahui rata-rata nilai yang diperoleh siswa dalam mengidentifikasi unsur kata konkret, nilai rata-rata tersebut diklasifikasikan berdasarkan nilai kemampuan menurut Sudjiono (2009:740). Jadi nilai rata-rata yang diperoleh adalah 60.4. Dengan demikian dapat 
disimpulkan bahwa kemampuan siswa dalam mengidentifikasi kata konkret tergolong dalam kategori sangat kurang.

Kesulitan siswa dalam mengidentifikasi kata konkret disebabkan kurangnya pemahaman siswa membedakan kata konkret dengan pengimajian. Kata konkret adalah penyebab terjadinya imaji. Kata konkret menggunakan bahasa atau ungkapan yang lebih nyata namun sang pembaca atau pendengar puisi harus memiliki pemikiran yang lebih agar dapat memahami, dan disinilah siswa merasa sulit dan tidak mengerti dalam membedakan hal tersebut.

\section{g. Kemampuan Mengidentifikasi Pengimajian}

Pengimajian merupakan salah satu aspek penilaian dalam mengidentifikasi unsur intrinsik puisi. Dalam aspek nilai maksimal yang harus diperoleh adalah 5. Siswa yang mendapat skor 5 sebanyak 2 siswa, skor 3 sebanyak 21 orang dengan perolehan nilai rata-rata 3.36 .

Untuk mengetahui rata-rata nilai yang diperoleh siswa dalam mengidentifikasi unsur pengimajian, nilai rata-rata tersebut diklasifikasikan berdasarkan nilai kemampuan menurut Sudjiono (2009:740). Jadi nilai rata-rata yang diperoleh adalah 67.2. Dengan demikian dapat disimpulkan bahwa kemampuan siswa dalam mengidentifikasi pengimajian tergolong dalam kategori cukup. Kesulitan yang ditemukan dalam aspek ini tidak ada karena pengimajian menyangkut hal-hal yng erkenaan dengan panca indera. Namun ada saja sebagian siswa yang mengabaikan sehingga presentasi yang diperoleh masih bersifat cukup.

\section{PENUTUP}

Kemampuan siswa kelas X SMA Negeri 1 Pahae Julu Tahun pembelajaran 2016/2017 dalam mengidentifikasi unsur intrinsik puisi tanpa menggunakan strategi Kekuatan Berdua dapat dilihat dari rata-rata pre test siswa sebesar 50 dengan kategori kurang.

Kemampuan siswa kelas X SMA Negeri 1 Pahae Julu Tahun pembelajaran 2016/2017 dalam mengidentifikasi unsur intrinsik puisi setelah diberi perlakuan dengan strategi Kekuatan Berdua dapat dilihat dari rata-rata post test siswa sebesar 61.5 dengan kategori cukup.

Penggunaan Strategi Kekuatan Berdua efektif digunakan untuk meningkatkan kemampuan mengidentifikasi unsur intrinsik siswa kelas X SMA Negeri 1 Pahae Julu Tahun Pembelajaran 2016/2017. Ini ditunjukkan dengan adanya peningkatan dari hasil pre test dan post test siswa. 


\section{DAFTAR PUSTAKA}

Arikunto.2013.Prosedur Penelitian: Suatu Pendekatan Praktik. Cetakan Kelimabelas. Jakarta. Rineka Cipta.

Indriani, Made.2006. Meningkatkan Kemampuan Menganalisis Puisi Dengan Pengajaran Pemahaman Unsur Intrinsik Karya Sastra Untuk Meningkatkan Kemampuan Menganalisis Puisi Siswa Kelas III A1 Sma Negeri 2 Singaraja. Jurnal Pendidikan dan Pengajaran No 2. Diambil dari : http://pasca.undiksha.ac.id/image/.

Muhajidin. (2012). "Keefektifan Pembelajaran Apresiasi Puisi Dengan Analisis Struktural Dan Analisis Semotk Berdasarkan Gaya Berpikir Sekuensial- $\quad$ Acak Pada Siswa SMP” .Jurnal Pendidikan. Halaman 130.

Ngalimun. 2012. Strategi Dan Model Pembelajaran. Banjarmasin: Aswaja Pressindo.

Rahayu.(2011). Penerapan Strategi Pembelajaran The Power Of Two dalam Upaya Meningkatkan Hasil Belajar Aqidah Akhlak Siswa Kelas VII.1 Mts Syaroful Millah Penggaron Kidul Semarang. Skripsi Fakultas Tarbiyah. Jurusan Ilmu Tarbiyah.

Resti,Yuanita. (2012). Penerapan Strategi Pembelajaran Aktif Tipe The Power Of Two Dengan Media Gambar untuk Meningkatkan Kreativitas Dan Prestasi Belajar Bahasa Indonesia ii Kelas VIIA Mts Yogyakarta.Skripsi. Yogyakarta.Jurusan Satu Pendidikan Islam

Sanjaya, W. 2012. Strategi Pembelajaran Berorientasi Standar Proses Pendidikan. Bandung : Kencana Prenada Media Group

Sudijono, Anas. 2009. Pengantar Statistik Pendidikan. Jakarta: Raja Grafindo Persada

Sugiyono. 2013. Metode Penelitian Pendidikan Pendekatan Kuantitatif, Kualitatif, Dan $R \& D$. Bandung. Penerbit Alfabeta. 